\title{
Effects on Cell Growth, Lipid and Biochemical Composition of Thalassiosira weissflogii (Bacillariophyceae) Cultured under Two Nitrogen Sources
}

\author{
Francisco Eduardo Hernández-Sandoval ${ }^{1, *} \mathbb{0}$, Jorge Arturo Del Ángel-Rodríguez ${ }^{2, *} \mathbb{C}$, Erick Julian Núñez-Vázquez ${ }^{1, *}$, \\ Christine Johanna Band-Schmidt ${ }^{3}{ }^{\circledR}$, Bertha Olivia Arredondo-Vega ${ }^{1}$, Ángel Isidro Campa-Córdova ${ }^{1}$, \\ Manuel Moreno-Legorreta ${ }^{1}$, Leyberth José Fernández-Herrera ${ }^{3}$ and David Javier López-Cortés ${ }^{1,+}$ \\ check for \\ updates \\ Citation: Hernández-Sandoval, F.E.; \\ 1 Centro de Investigaciones Biológicas del Noroeste (CIBNOR), La Paz 23096, Mexico; \\ kitty04@cibnor.mx (B.O.A.-V.); angcamp04@cibnor.mx (Á.I.C.-C.); legoreta04@cibnor.mx (M.M.-L.) \\ 2 Department of Ocean Sciences, Memorial University of Newfoundland, St. John's, NL A1K 3E6, Canada \\ 3 Departamento de Plancton y Ecología Marina, Centro Interdisciplinario de Ciencias Marinas (IPN-CICIMAR), \\ Instituto Politécnico Nacional, La Paz 23096, Mexico; cbands@ipn.mx (C.J.B.-S.); \\ lfernandezh1200@alumno.ipn.mx (L.J.F.-H.) \\ * Correspondence: fhernan04@cibnor.mx (F.E.H.-S.); jadar7@mun.ca (J.A.D.Á.-R.); \\ enunez04@cibnor.mx (E.J.N.-V.) \\ + Deceased.
} Del Ángel-Rodríguez, J.A.;

Núñez-Vázquez, E.J.;

Band-Schmidt, C.J.;

Arredondo-Vega, B.O.;

Campa-Córdova, Á.I.;

Moreno-Legorreta, M.;

Fernández-Herrera, L.J.;

López-Cortés, D.J. Effects on Cell

Growth, Lipid and Biochemical

Composition of Thalassiosira

weissflogii (Bacillariophyceae)

Cultured under Two Nitrogen

Sources. Appl. Sci. 2022, 12, 961.

https://doi.org/10.3390/

app12030961

Academic Editor: Birthe

Vejby Nielsen

Received: 8 November 2021

Accepted: 13 January 2022

Published: 18 January 2022

Publisher's Note: MDPI stays neutral with regard to jurisdictional claims in published maps and institutional affiliations.

Copyright: (C) 2022 by the authors. Licensee MDPI, Basel, Switzerland. This article is an open access article distributed under the terms and conditions of the Creative Commons Attribution (CC BY) license (https:// creativecommons.org/licenses/by/ $4.0 /)$.

\begin{abstract}
The protein and polyunsaturated fatty acid (PUFA) enrichment of microalgae can improve their nutritional value for larvae of various reared organisms. Protein enrichment can be achieved by increasing nitrogen concentration and selecting nitrogen sources that are easy to assimilate during microalga culture. Nitrogen-rich cultures can increase organism growth, biomass, and protein content, but their lipid content tends to stall. Since the diatom Thalassiosira weissflogii is usually provided to feed shrimp larvae, this study evaluated its digestibility and biochemical composition, culturing it with two nitrogen sources $\left(\mathrm{NaNO}_{3}\right.$ and $\left.\mathrm{NH}_{4} \mathrm{Cl}\right)$ at different concentrations $(111.25,222.50,445$ and $890 \mu \mathrm{M})$. The cell abundance, dry-weight biomass, Chl $a$, proteins, carbohydrates, total lipids and essential fatty acids were determined. The cell density and biomass peaked faster (day 12) with treatment $<890 \mu \mathrm{M}$ than with $890 \mu \mathrm{M}$ (day 15) in both nitrogen sources. However, the highest cell density, biomass and peak protein yield were not significantly different among treatments, suggesting the need to compare maintenance costs for a given production. After nine days of culture, concentrations $\leq 222.5 \mu \mathrm{M}$ increased lipid content irrespective of the nitrogen source and decreased by $10-20 \%$ afterwards. With higher lipid production, the dominant PUFA were eicosapentaenoic acid (EPA) and docosahexaenoic acid (DHA). One gram of $\mathrm{NH}_{4} \mathrm{Cl}$ provides $\sim 60 \%$ more nitrogen than $1 \mathrm{~g}$ of $\mathrm{NaNO}_{3}$. In conclusion, based on time and growth rate, T. weissflogii cultivated with $\mathrm{NH}_{4} \mathrm{Cl}$ at $222.50 \mu \mathrm{M}$ produced EPA and DHA at a better yield-cost ratio for biomass and lipid production. Furthermore, its nutritional value as enriched live-food for the reared larvae of marine organisms suggests potential biotechnological applications for aquaculture.
\end{abstract}

Keywords: biotechnological aquaculture; biochemical composition; fatty acid; nitrogen source; algal application

\section{Introduction}

In the last few years, interest in aquaculture has increased worldwide because of the growing market demand and high commercial value created by these products [1]. Their production success is undoubtedly related to the quality and quantity of the food supplied [2]. Microalgae are traditionally used in aquaculture for larval growth. Nevertheless, although attempts have been conducted to substitute natural food with microencapsulates, yeast or bacteria, the poor enzymatic activity and nonfunctional stomach of larvae do not 
allow them to digest formulated diets completely [3,4]. Accordingly, natural microalgae are still considered as the main live food source for marine larvae [2,5].

As a consequence of their nutritional value, diatom species, such as Skeletonema costatum, Thalassiosira sp., Phaeodactylum sp., Chaetoceros gracilis, C. calcitrans and the flagellates Pavlova lutheri, Isochrysis galbana, Tetraselmis chuii and T. suecica are all grown as food for rearing marine organisms of commercial value [6,7]. Their biochemical composition is important for their nutritional value because of their ability to synthesize and accumulate essential fatty acids and other nutrients [8,9].

Among the species previously mentioned, Thalassiosira weissflogii has been provided successfully for feeding shrimp larvae [10] because of its shape, digestibility and biochemical composition [11], which can vary as a result of changes in the environment [12-14]. Thus, the effects of temperature, salinity, $\mathrm{pH}$, nutrients and their interactions have been addressed [14-16]. Additionally, the growth phase is recognized as an important factor influencing the biochemical composition of microalgae. For example, during the stationary phase, when nitrogen becomes limiting, microalgae shift their metabolism to carbohydrate and lipid production [17]. Among all the physical-chemical factors, nitrogen influences lipid metabolism and its deficient conditions increase fatty acid concentration in various microalgae [18,19]. Nitrogen in the form of nitrate, ammonia or urea (or their combinations) is added to most media for commercial aquaculture in high concentrations and changes in nitrogen supply are known to strongly influence the growth and biochemical composition of microalgae [20]. Furthermore, nitrogen is easy to manipulate and less expensive compared to other growth factors. Comparatively few studies have analyzed the effects of different nitrogen sources on the biochemical composition of the diatom T. weissflogii. Therefore, this study evaluated different concentrations of two nitrogen sources, sodium nitrate $\left(\mathrm{NaNO}_{3}\right)$ and ammonium chloride $\left(\mathrm{NH}_{4} \mathrm{Cl}\right)$, on the growth, biochemical composition (protein, carbohydrate and lipid) and main fatty acids in the microalga T. weissflogii.

\section{Materials and Methods}

\subsection{Strain and Culture}

Thalassiosira weissflogii (CIB-85 strain) was acquired by donation of CITMA (Ministerio de Ciencia y Tecnología y Medio Ambiente de Cuba; https: / / www.citma.gob.cu (accessed on 6 November 2021). The species was grown in batch cultures in $2.5 \mathrm{~L}$ Fernbach glass flasks (Thermo Fisher Scientific, Waltham, MA, USA) with $\mathrm{f} / 2+$ Si media [21]. Culture conditions were: illumination of $120 \mu \mathrm{mol}$ photon $\mathrm{m}^{-2} \mathrm{~s}^{-1}$, continuous aeration, photoperiod of $12 \mathrm{~h}: 12 \mathrm{~h} \mathrm{light/dark} \mathrm{cycle,} \mathrm{and} \mathrm{temperature} \mathrm{of} 22 \pm 0.5^{\circ} \mathrm{C}$.

\subsection{Experimental Design}

Culture media $\mathrm{f} / 2+\mathrm{Si}$ for experiments was initially prepared without nitrogen. The selected nitrogen source and concentration was added posteriorly (Table 1). Each experimental combination was assayed in quadruplicate cultures (i.e., $8 \times 4=32$ ). All treatments were inoculated with an initial concentration of $2.37 \times 10^{5}$ cells $\mathrm{mL}^{-1}$. Cultures were progressively conditioned to each nitrogen concentration from an initial condition of $890 \mu \mathrm{M}$. The cells were adapted for three generations to each treatment before starting the batch culture. The experiment was conducted for 18 days.

\subsection{Growth and Biomass Production}

Cell density and dry biomass were monitored every third day using seven replicates for each sample (i.e., $8 \times 7=56 /$ day). Cell counts were performed on a Neubauer chamber (VWR SCIENTIFIC, superior, VWR International, Radnor, PA, USA).

Cell growth was evaluated using two models: the first one was via the logistic growth model, [22-24].

$$
d N_{t} / d t=r N\left[\left(k-N_{t}\right) / k\right],
$$

where $t$ is time (h); $N_{t}$ is the cell density (cells $\mathrm{mL}^{-1}$ ) at time $t ; r$ is the proportionality constant $\left(\mathrm{h}^{-1}\right)$; and $k$ is the carrying capacity of the system (cells $\mathrm{mL}^{-1}$ ) or maximum cell 
density $\left(N_{\max }\right)$ reached at the end of the exponential phase. The value $k / 2$, which is half the carrying capacity (cells $\mathrm{mL}^{-1}$ ), was also estimated, and $t_{k / 2}$ represents the estimated time $(\mathrm{h})$ to reach half of the carrying capacity. For this model, the non-linear regression parameters were estimated via the iterative process to reach the least sum of squares (SSQ).

Table 1. Sources and concentrations of nitrogen used in Thalassiosira weissflogii experimental culture media.

\begin{tabular}{ccc}
\hline $\begin{array}{c}\text { Concentration } \\
(\mu \mathbf{M})\end{array}$ & $\begin{array}{c}\text { Treatments } \\
\left(\mathbf{N H}_{\mathbf{4}} \mathbf{C l}\right)\end{array}$ & $\begin{array}{c}\text { Treatments } \\
\left(\mathbf{N a N O}_{3}\right)\end{array}$ \\
\hline 111.25 & $\mathrm{C} 1$ & $\mathrm{~N} 1$ \\
\hline 222.5 & $\mathrm{C} 2$ & $\mathrm{~N} 2$ \\
\hline 445 & $\mathrm{C} 3$ & $\mathrm{~N} 3$ \\
\hline 890 & $\mathrm{C} 4$ & $\mathrm{~N} 4$ \\
\hline
\end{tabular}

Additionally, two other parameters were estimated. The first was maximum specific growth rate $\mu\left(\mathrm{h}^{-1}\right)$, calculated by the equation $[25,26]$ :

$$
u_{\max }=\ln \left(k / N_{1}\right) /\left(t_{k}-t_{1}\right),
$$

where $t_{k}$ is time at the end of the exponential phase, and $t_{1}$ and $N_{1}$ are time and cell density at the beginning of the exponential phase, respectively. The second parameter was population doubling time (h), estimated as, [27]:

$$
P D T=\ln 2 / u,
$$

The second model was an exponential rise to the maximum of the form: $N_{t}=N_{0}+a\left(1-\mathrm{e}^{(-b \cdot t)}\right)$, where cell density increase is represented by parameter $a$, and estimated growth rate is estimated by parameter $b$. For this model, time values were represented as days, thus at the beginning of the experiment:

$$
(\mathrm{t}=0) N_{t}=N_{0},
$$

Nonlinear regressions were performed using the preset model for exponential rise to maximum, with three parameters, available in Sigmaplot Version 12.

Dry biomass was determined every $48 \mathrm{~h}$ by filtering $10 \mathrm{~mL}$ of culture through preweighed and pre-burned GF/F glass-fiber filter, $0.7 \mu \mathrm{m}$ pore size (Whatman, Maidstone, UK). Biomass was further washed with $0.5 \mathrm{M}$ ammonium formate to remove salt precipitates and dried at $60^{\circ} \mathrm{C}$ for $24 \mathrm{~h}$. The weight difference between the filter and the filter with the sample was determined.

\subsection{Biochemical Composition}

Biochemical composition was also monitored every $48 \mathrm{~h}$, using seven replicates for each sample. A sample of $100 \mathrm{~mL}$ was obtained and centrifuged at $1658 \times g$ (BECKMAN GPR Centrifuge, CA, USA) for $15 \mathrm{~min}$ at $5{ }^{\circ} \mathrm{C}$, and further lyophilized (LABCONCO 5.0 Liter, Virtis Freeze Dryers, Kansas City, MO, USA).

\subsubsection{Total Protein}

Total protein content $(5 \mathrm{mg})$ of lyophilized microalgae was determined spectrophotometrically with the Folin-Phenol Reagent (Sigma-Aldrich, St. Louis, MO, USA) [28]. Bovine serum albumin (BSA) was used as a standard (Sigma Aldrich STD). Samples were analyzed at $570 \mathrm{~nm}$ with a spectrophotometer (Beckman DU 640, spectrophotometer Beckman Coulter, Inc. Pasadena, CA, USA). 


\subsubsection{Total Carbohydrates}

The carbohydrate content of $5 \mathrm{mg}$ lyophilized microalgae was analyzed according to the sulfuric acid colorimetric method [29], based on phenolphthalein absorbance. Samples were analyzed at $490 \mathrm{~nm}$ (Beckman DU 640 spectrophotometer Beckman Coulter, Inc.).

\subsubsection{Chlorophyll $a$}

Two mg of lyophilized algae were extracted with $4 \mathrm{~mL}$ of acetone $100 \%$ HPLC grade (high performance liquid chromatography). Samples were stored at $-20^{\circ} \mathrm{C}$ every $24 \mathrm{~h}$. Extract was recovered after centrifugation $\left(1658 \times g\right.$ at $5{ }^{\circ} \mathrm{C}$ for $\left.15 \mathrm{~min}\right)$. Chlorophyll $a$ (Chl $a$ ) was separated and quantified by HPLC (Mod. 1100, Hewlett Packard, CA, USA), as described in [30]. The mobile phase consisted of $\mathrm{MeOH}: 1 \mathrm{~N}$ aqueous ammonium acetate, $70: 30 \% v / v$ (solvent A), and MeOH (solvent B). A C8 MOS Hypersil column $10 \mathrm{~cm} \times 0.45 \mathrm{~cm}, 5 \mu \mathrm{m}$ particle size was used with standards for identification and quantification. For the identification of pigments, retention time standards (RST) (International Agency for ${ }^{14} \mathrm{C}$ determinations, Denmark, DHI-Denmark, PPS-CHLA) and absorption spectra $(350-750 \mathrm{~nm})$ were considered.

\subsubsection{Total Lipids}

The total content of lipids were extracted according to the method [31], where $5 \mathrm{mg}$ of lyophilized microalgae was added to $2 \mathrm{~mL}$ chloroform: methanol $(2: 1 v / v)$ HPLC grade at $4{ }^{\circ} \mathrm{C}$ for $24 \mathrm{~h}$. Extracts were centrifuged at $1658 \times g$ for $20 \mathrm{~min}$, and the supernatant was collected. Distilled water was added until the system became biphasic. The lower chloroform layer was separated and dried under nitrogen $\left(\mathrm{N}_{2}\right)$ flow. Lipids were quantified accordingly [32], which involved organic matter carbonization with sulfuric acid, using triestearine as the standard. Samples were analyzed at $375 \mathrm{~nm}$ with a spectrophotometer (Beckman DU 640, Beckman Coulter, Inc.).

\subsubsection{Fatty Acid Composition and Statistical Analyses}

Methanolysis of fatty acids with $\mathrm{HCl}: \mathrm{CH}_{3} \mathrm{OH}(5: 95 \mathrm{v} / \mathrm{v})$ was performed as described in [33]. Methyl ester extract was evaporated to dryness under a stream of $\mathrm{N}_{2}$. The resulting methyl esters were resuspended in $n$-hexane HPLC. The extract was injected into a gas chromatograph mass spectrometer with an electronic ionization detector (GCD Plus Hewlett Packard, model G1800B) equipped with an Omega Wax Column (30 m $\times 0.25 \mathrm{~mm} \times 0.25 \mu \mathrm{m})$. Oven temperature was programmed as follows: initially $110^{\circ} \mathrm{C}$ with $280{ }^{\circ} \mathrm{C}$ as the maximum temperature. The flame detector temperature was $260^{\circ} \mathrm{C}$. The carrier gas utilized was

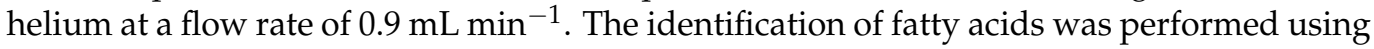
two criteria: (1) retention time of methylated standard and (2) presence of the characteristic ion mass / charge $(m / z)$. Different fatty acid methyl esters (FAME chemical standard, Sigma Aldrich) were used to determine retention time and response factor of each fatty acid.

The results for biochemical composition and cell growth were analyzed by a multifactorial analysis of variance (ANOVA) considering nitrogen source, nitrogen concentration and time as factors. The level of significance was $\alpha=0.05$ [34]. All analyses were carried out using STATISTICA ${ }^{\circledR}$ software v.6.0 (Statsoft, Tulsa, OK, USA).

\section{Results}

\subsection{Growth and Biomass Production of Microalgae}

As expected, the T. weissflogii peak cell density $(k)$ improved significantly $(p<0.05)$ when the nitrogen concentration increased from 111.25 to $890 \mu \mathrm{M}$. According to the sigmoidal curve model (Table 2), the highest $\mathrm{NaNO}_{3}(\mathrm{~N} 4)$ concentration produced the largest cell density $\left(>12.5 \times 10^{6}\right.$ cells $\left.\mathrm{mL}^{-1}\right)$ at the end of the exponential phase. However, the highest $\mathrm{NH}_{4} \mathrm{Cl}(\mathrm{C} 4)$ concentration yielded a similar cell density ( $6 \%$ less) but with a higher proportionally constant $(r)\left(0.385\right.$ vs. $\left.0.275 \mathrm{~h}^{-1}\right)$. Accordingly, the estimated time to reach half of the maximum cell density $\left(t_{k / 2}\right)$ occurred $33 \mathrm{~h}$ earlier for C4 compared with $\mathrm{N} 4$. In general, $T$. weissflogii reached $t_{k / 2} 7-30 \mathrm{~h}$ earlier when the nitrogen source was $\mathrm{NH}_{4} \mathrm{Cl}$. 
The exponential rise model (Table 3, bottom) also confirmed higher final cell densities (a parameter) for $\mathrm{N} 4$ and C4, but they were not significantly different. Within this model, the estimated growth rate ( $b$ parameter) was not significantly different among similar concentrations of different nitrogen sources.

Table 2. Parameter estimations of Thalassiosira weissflogii growth curves with two different nitrogen sources at different concentrations via different models.

\begin{tabular}{|c|c|c|c|c|c|c|c|c|}
\hline & \multicolumn{4}{|c|}{$\mathrm{NaNO}_{3} \mu \mathrm{mol}$} & \multicolumn{4}{|c|}{$\mathrm{NH}_{4} \mathrm{Cl} \mu \mathrm{mol}$} \\
\hline Treatment & N1 & N2 & N3 & N4 & C1 & $\mathrm{C} 2$ & C3 & $\mathrm{C} 4$ \\
\hline$\mu \mathrm{mol} \mathrm{L}{ }^{-1}$ [as Salt] & 111.25 & 222.50 & 445.00 & 890.00 & 111.25 & 222.50 & 445.00 & 890.00 \\
\hline \multirow[t]{2}{*}{$\mu \mathrm{g} \mathrm{L}^{-1}[\mathrm{~N}]$} & 18.33 & 36.67 & 73.33 & 146.67 & 29.13 & 58.26 & 116.52 & 233.05 \\
\hline & \multicolumn{8}{|c|}{ Parameter estimation of the sigmoidal curve via least squares (SSQ) } \\
\hline$N_{0}\left(\right.$ cells $\left.\mathrm{mL}^{-1}\right)$ & 507,498 & 416,176 & 505,885 & 457,116 & 473,424 & 439,717 & 485,535 & 426,034 \\
\hline$r\left(\mathrm{~h}^{-1}\right)$ & 0.0304 & 0.0221 & 0.0351 & 0.0275 & 0.0358 & 0.0294 & 0.0367 & 0.0385 \\
\hline$k$ or $N_{\max }\left(\right.$ cells $\left.\mathrm{mL}^{-1}\right)$ & $5,378,478$ & $8,360,922$ & $9,553,601$ & $12,580,306$ & $5,589,747$ & $7,700,407$ & $7,921,201$ & $11,852,018$ \\
\hline$\% \max k$ & 43 & 66 & 76 & 100 & 44 & 61 & 63 & 94 \\
\hline k/2 (cells mL $\left.{ }^{-1}\right)$ & $2,689,239$ & $4,180,461$ & $4,776,801$ & $6,290,153$ & $2,794,873$ & $3,850,203$ & $3,960,600$ & $5,926,009$ \\
\hline \multirow[t]{2}{*}{$t_{k / 2}$ (hours) } & 74 & 134 & 82 & 119 & 67 & 95 & 75 & 86 \\
\hline & \multicolumn{8}{|c|}{ Formula estimation of $\mu$ and PDT } \\
\hline$\mu_{\max }\left(\mathrm{h}^{-1}\right)$ & 0.0111 & 0.0125 & 0.0133 & 0.0114 & 0.0117 & 0.0130 & 0.0129 & 0.0118 \\
\hline \multirow[t]{2}{*}{ PDT (hours) } & 62.2 & 55.3 & 52.2 & 60.8 & 59.4 & 53.3 & 53.9 & 58.8 \\
\hline & \multicolumn{8}{|c|}{ Parameter estimation of an exponential rise to maximum model via non-linear regression (Note $t$ (days) } \\
\hline$b$ & 0.343 & 0.114 & 0.241 & 0.122 & 0.277 & 0.173 & 0.295 & 0.145 \\
\hline $95 \%$ CI $b$ & 0.264 & 0.064 & 0.087 & 0.040 & 0.173 & 0.080 & 0.135 & 0.044 \\
\hline$a$ & $4,349,873$ & $9,604,878$ & $9,306,673$ & $15,151,914$ & $5,246,430$ & $8,220,818$ & $7,207,902$ & $14,152,484$ \\
\hline $95 \%$ CI $a$ & 851,406 & $2,393,787$ & $1,012,272$ & $2,163,974$ & 931,908 & $1,363,124$ & 902,546 & $1,691,236$ \\
\hline
\end{tabular}

Values represent equations 1 and 2 parameters and therefore describe the whole growth curves.

Table 3. Total protein, carbohydrate and lipid contents (mean value and standard deviation) of Thalassiosira weissflogii dry biomass at different days, cultured at four different nitrogen concentrations of $\mathrm{NaNO}_{3}$.

\begin{tabular}{|c|c|c|c|c|c|}
\hline & \multirow[b]{2}{*}{$\mathrm{NaNO}_{3} \mu \mathrm{mol}$} & \multicolumn{4}{|c|}{ Time (Days) } \\
\hline & & 3 & 9 & 15 & 18 \\
\hline \multirow{4}{*}{$\begin{array}{c}\text { Protein } \\
\left(\mu \mathrm{g} \mathrm{mg} \mathrm{m}^{-1}\right)\end{array}$} & 111.25 & $74.7 \pm 9.5$ & $88.5 \pm 7.1$ & $77.5 \pm 12.7$ & $45.2 \pm 7.7$ \\
\hline & 222.50 & $158.9 \pm 12.0$ & $123.7 \pm 43.4$ & $116.6 \pm 19.1$ & $96.27 \pm 2.5$ \\
\hline & 445 & $325.1 \pm 63.4$ & $200.0 \pm 24.4$ & $183.4 \pm 2.2$ & $144.7 \pm 7.5$ \\
\hline & 890 & $351.4 \pm 22.8$ & $239.7 \pm 36.5$ & $232.9 \pm 3.6$ & $185.6 \pm 10.5$ \\
\hline \multirow{4}{*}{$\begin{array}{l}\text { Carbohydrates } \\
\left(\mu g \mathrm{mg}^{-1}\right)\end{array}$} & 111.25 & $178.0 \pm 27.7$ & $300.4 \pm 9.7$ & $399.4 \pm 50.3$ & $290.2 \pm 9.9$ \\
\hline & 222.50 & $188.8 \pm 70.5$ & $386.7 \pm 10.9$ & $312.8 \pm 48.7$ & $436.6 \pm 5.3$ \\
\hline & 445 & $216.5 \pm 66.7$ & $274.1 \pm 36.7$ & $334.1 \pm 43.0$ & $272.1 \pm 64.7$ \\
\hline & 890 & $215.8 \pm 15.4$ & $253.7 \pm 10.0$ & $238.5 \pm 7.4$ & $211.5 \pm 5.8$ \\
\hline \multirow{4}{*}{$\begin{array}{l}\text { Lipids } \\
\left(\mu \mathrm{g} \mathrm{mg} \mathrm{mg}^{-1}\right)\end{array}$} & 111.25 & $318.6 \pm 22.0$ & $494.5 \pm 10.5$ & $447.1 \pm 20.9$ & $370.1 \pm 8.7$ \\
\hline & 222.50 & $338.9 \pm 31.2$ & $460.4 \pm 51.1$ & $388.2 \pm 22.4$ & $356.4 \pm 40.2$ \\
\hline & 445 & $244.8 \pm 5.7$ & $349.1 \pm 44.2$ & $340.3 \pm 38.7$ & $268.5 \pm 32.8$ \\
\hline & 890 & $240.0 \pm 10.1$ & $281.9 \pm 61.9$ & $335.5 \pm 12.5$ & $289.1 \pm 13.3$ \\
\hline
\end{tabular}

Diatom T. weissflogii treated with $\mathrm{NaNO}_{3}$ and $\mathrm{NH}_{4} \mathrm{Cl}$ concentrations of 222.5 and $445 \mu \mathrm{mol} \mathrm{L}^{-1}$ (N2, N3, C2 and C3), respectively, achieved population duplication times $(P D T)<56 \mathrm{~h}$, which suggests that moderate salt concentrations provided concentrations close to the optimum nitrogen amounts required for cell duplication, i.e., neither limited nor in excess. With the $890 \mu \mathrm{M}$ treatment, $\mathrm{NaNO}_{3}$ reached a plateau in biomass production $\left(\sim 0.4 \mathrm{mg} \mathrm{mL}^{-1}\right)$ around day 12 and remained at similar levels until day 18. By contrast, the treatment with $890 \mu \mathrm{M} \mathrm{NH}{ }_{4} \mathrm{Cl}$ reached a similar peak value $\left(\sim 0.4 \mathrm{mg} \mathrm{mL}^{-1}\right)$ until day 15 but rapidly decreased at day 18 . The rest of the treatments did not exceed a biomass concentration of $0.250 \mathrm{mg} \mathrm{mL}^{-1}$.

The cell density (cell $\mathrm{mL}^{-1}$ ) correlated positively with the dry weight measurements $\left(\mathrm{mg} \mathrm{mL}{ }^{-1}\right)$ for both nitrogen sources. For $\mathrm{NaNO}_{3}$, the slope was $2.45 \times 10^{-8} \mathrm{mg} \mathrm{cell}^{-1}$, 
$\mathrm{R}^{2}=0.93$ and $p<0.05$, whereas for $\mathrm{NH}_{4} \mathrm{Cl}$ the slope was $2.53 \times 10^{-8} \mathrm{mg}$ cell ${ }^{-1}, \mathrm{R}^{2}=0.95$ and $p<0.05$. Furthermore, no significant differences were observed between slopes for both sources (ANCOVA Source $p=0.172$ ).

\subsection{Biochemical Composition}

\subsubsection{Chlorophyll $a$}

The chlorophyll $a$ content in T. weissflogii increased with time and nitrogen concentration $(p<0.001)$. However, the time to reach peak production varied depending on the source and concentration. For instance, $\mathrm{NaNO}_{3}$ and $\mathrm{NH}_{4} \mathrm{Cl}$ treatments with $111.25 \mu \mathrm{M}$ reached small peak chlorophyll $a$ (2500-3900 $\mathrm{ng} \mathrm{mg}^{-1}$ dry weigh) values earlier (day 12). By contrast, treatments with $890 \mu \mathrm{M}$ yielded the highest chlorophyll a production, with similar results at peak production (7084-7199 and 7039-8691 $\mathrm{ng} \mathrm{mg}^{-1}$ dry weight for $\mathrm{NaNO}_{3}$ and $\mathrm{NH}_{4} \mathrm{Cl}$, respectively). However, with $\mathrm{NaNO}_{3}$, the peak was reached at the end of the experiment (day 18), whereas for $\mathrm{NH}_{4} \mathrm{Cl}$, it was reached three days earlier (day 15).

\subsubsection{Proteins, Carbohydrates and Lipids}

As expected, with both salts, a clear tendency was observed towards an increase in protein content as a consequence of an increase in nitrogen concentration $(p<0.05)$. However, this difference was not sustained throughout the experiment. This result is common in batch cultures without nitrogen replenishment. As the microalgae grew, moderate-to-strong nitrogen depletion decreased amino acid synthesis, as was expected. For instance, at the onset of the experiment (day 3), a significantly high protein concentration $\left(\sim 390 \mu \mathrm{g} \mathrm{mg}{ }^{-1}\right)$ was observed in the $890 \mu \mathrm{M}$-treated $\mathrm{NH}_{4} \mathrm{Cl}$ and $\mathrm{NaNO}_{3}$, as well as in the $445 \mu \mathrm{M}$-treated $\mathrm{NaNO}_{3}$. As the experiment progressed, protein concentration decreased, reaching concentrations of $<220 \mu \mathrm{g} \mathrm{mg}^{-1}$ by day 18 . A high decrease, from 47 to $57 \%$, in protein content was observed in very low (N1 and C1), moderately high (N3 and C3) and high (N4 and C4) nitrogen salt concentrations with time. Moderately low salt concentrations (C2 and N2) initially yielded lower protein concentrations but showed less variation with time. In this case, the decline in protein concentration during the experiment was $39 \%$ for $\mathrm{NaNO}_{3}$ and $31 \%$ for $\mathrm{NH}_{4} \mathrm{Cl}$ (Tables 3 and 4 ).

Table 4. Total protein, carbohydrate and lipid contents (mean value and standard deviation) of Thalassiosira weissflogii dry biomass at different days cultured at four different nitrogen concentrations of $\mathrm{NH}_{4} \mathrm{Cl}$.

\begin{tabular}{cccccc}
\hline & \multicolumn{5}{c}{ Time (Days) } \\
\hline & $\mathbf{N H}_{\mathbf{4}} \mathbf{C l} \boldsymbol{\mu \mathbf { m o l }}$ & $\mathbf{3}$ & $\mathbf{9}$ & $\mathbf{1 5}$ & $\mathbf{1 8}$ \\
\hline & 111.25 & $126.5 \pm 10.5$ & $72.21 \pm 20.9$ & $124.4 \pm 16.6$ & $102.9 \pm 11.8$ \\
Protein & 222.50 & $143.4 \pm 22.8$ & $146.8 \pm 11.8$ & $165.8 \pm 5.8$ & $128.5 \pm 23.3$ \\
$\left(\mu \mathrm{g} \mathrm{mg}^{-1}\right)$ & 445 & $230.2 \pm 16.0$ & $238.3 \pm 52.1$ & $171.2 \pm 43.7$ & $183.8 \pm 56.7$ \\
& 890 & $393.1 \pm 68.5$ & $242.3 \pm 12.5$ & $218.7 \pm 6.9$ & $199.4 \pm 11.5$ \\
\hline & 111.25 & $350.9 \pm 45.9$ & $354.3 \pm 22.2$ & $279.9 \pm 45.6$ & $279.1 \pm 22.9$ \\
Carbohydrates $_{\left(\mu \mathrm{gg}^{-1}\right)}$ & 222.50 & $351.7 \pm 106.9$ & $385.6 \pm 13.6$ & $380.9 \pm 29.1$ & $266.6 \pm 21.4$ \\
& 445 & $205.1 \pm 77.4$ & $348.6 \pm 20.3$ & $284.2 \pm 20.6$ & $248.1 \pm 16.9$ \\
& 890 & $142.3 \pm 50.6$ & $353.0 \pm 54.3$ & $271.6 \pm 34.8$ & $267.9 \pm 30.0$ \\
\hline & 111.25 & $378.6 \pm 10.5$ & $497.7 \pm 11.1$ & $404.7 \pm 17.7$ & $387.6 \pm 11.1$ \\
Lipids $\left._{(\mu \mathrm{g} \mathrm{mg}}^{-1}\right)$ & 222.50 & $48.6 \pm 28.3$ & $450.9 \pm 28.2$ & $404.8 \pm 0.08$ & $425 \pm 14.4$ \\
& 445 & $263.1 \pm 10.8$ & $328.6 \pm 24.3$ & $414.2 \pm 12.0$ & $309.4 \pm 7.2$ \\
& 890 & $235.0 \pm 9.4$ & $319.8 \pm 6.54$ & $318.8 \pm 9.0$ & $309.2 \pm 14.9$ \\
\hline
\end{tabular}

The carbohydrate and lipid contents were influenced by the interaction between nitrogen concentration and culture age $(p<0.005)$ and not by the nitrogen source. The carbohydrate concentration was the least consistent in time and nitrogen concentration. For instance, during most of the experiment, carbohydrates showed higher concentrations with high $\mathrm{NH}_{4} \mathrm{Cl}$ concentrations ( $\mathrm{C} 3$ and $\mathrm{C} 4$ ) but no clear pattern was observed with time. 
By contrast, the $\mathrm{NaNO}_{3}$ cultures increased their carbohydrate concentration with time and increased, on most days, with low nitrogen concentration (Table 3).

As expected, the lipids reached highest concentrations at lower nitrogen concentrations. In the case of $\mathrm{NaNO}_{3}$, they reached a plateau of $\sim 460 \mu \mathrm{g} \mathrm{mg}^{-1}$ for $\mathrm{N} 2$ and $495 \mu \mathrm{g} \mathrm{mg}{ }^{-1}$ for $\mathrm{N} 1$ after day 6 . These values were not significantly different from those observed at day 9 or 12 , suggesting a relatively long stationary phase in terms of lipid yield. For the treatments with $\mathrm{NH}_{4} \mathrm{Cl}, \mathrm{C} 1$ and $\mathrm{C} 2$ reached a small plateau of $\sim 500$ and $450 \mu \mathrm{g} \mathrm{mg}^{-1}$ after day 9 and remained at similar values after day 12. In most treatments, the lipid content dropped after day 15, indicating a time limit for harvesting if maximum lipid concentrations are the main goal.

\subsection{Fatty Acids}

The T. weissflogii fatty acid pattern was divided based on the degree of saturation, namely SAFA (saturated fatty acid), MUFA (monounsaturated fatty acid) and PUFA (polyunsaturated fatty acid). During exponential growth, the microalgae tended to show similar fatty acid percentages between the two different nitrogen sources, but the fatty acid concentration differed ( $p>0.05)$.

In the $\mathrm{NaNO}_{3}$ cultures, SAFA constituted 53.52\%, PUFA 44.78\% and, in a lower proportion, MUFA contributed $1.69 \%$. In the $\mathrm{NH}_{4} \mathrm{Cl}$ cultures, SAFA was $50.16 \%$, PUFA $48.60 \%$ and, in a lower proportion, MUFA contributed $1.22 \%$. The T. weissflogii concentration of selected PUFAs varied widely as a consequence of nitrogen source and concentration (Table 5).

Table 5. Polyunsaturated fatty acid (PUFA), eicosapentaenoic acid (EPA) and docosahexaenoic acid (DHA) composition of Thalassiosira weissflogii growth in different nitrogen sources $(\mu \mathrm{M})$ and concentrations in $\mathrm{pg}$ cells ${ }^{-1}$ (mean $\pm \mathrm{SD}$ ). SD: standard deviation.

\begin{tabular}{|c|c|c|c|c|c|c|c|c|}
\hline \multirow[b]{2}{*}{ PUFA } & \multicolumn{4}{|c|}{$\mathrm{NaNO}_{3}(\mu \mathrm{M})$} & \multicolumn{4}{|c|}{$\mathrm{NH}_{4} \mathrm{Cl}(\mu \mathrm{M})$} \\
\hline & 111.25 & 222.5 & 445 & 890 & 111.25 & 222.5 & 445 & 890 \\
\hline $18: 2$ & $1.20 \pm 0.53$ & $1.59 \pm 0.46$ & $1.32 \pm 0.31$ & $2.96 \pm 0.83$ & $0.63 \pm 0.21$ & $0.97 \pm 0.38$ & $1.38 \pm 0.68$ & $1.52 \pm 0.37$ \\
\hline $18: 3$ & $3.03 \pm 1.13$ & $2.82 \pm 1.17$ & $2.58 \pm 1.91$ & $4.08 \pm 2.69$ & $1.33 \pm 0.29$ & $2.57 \pm 1.99$ & $3.53 \pm 1.29$ & $4.08 \pm 2.69$ \\
\hline $18: 4$ & $3.11 \pm 1.05$ & $4.86 \pm 1.82$ & $3.53 \pm 2.13$ & $5.95 \pm 4.67$ & $3.61 \pm 1.43$ & $3.14 \pm 1.90$ & $5.83 \pm 3.61$ & $1.89 \pm 1.45$ \\
\hline $20: 4$ & $0.014 \pm 0.04$ & $0.026 \pm 0.01$ & $0.059 \pm 0.04$ & $0.043 \pm 0.02$ & $0.01 \pm 0.0009$ & $0.01 \pm 0.006$ & $0.01 \pm 0.007$ & $0.02 \pm 0.009$ \\
\hline $20: 5 n 3$ (EPA) & $16.67 \pm 4.35$ & $7.58 \pm 2.48$ & $14.12 \pm 3.09$ & $7.29 \pm 1.14$ & $11.94 \pm 9.47$ & $16.91 \pm 4.73$ & $10.24 \pm 3.36$ & $11.04 \pm 6.67$ \\
\hline 22:6n3 (DHA) & $7.22 \pm 1.45$ & $4.37 \pm 3.02$ & $6.45 \pm 2.76$ & $9.24 \pm 3.69$ & $4.82 \pm 2.06$ & $8.38 \pm 2.01$ & $5.25 \pm 2.44$ & $6.77 \pm 4.16$ \\
\hline
\end{tabular}

The major fatty acids were eicosapentaenoic (EPA, 20:5n3) and docosahexaenoic (DHA, 22:6n3) acids, and both increased at higher $\mathrm{NaNO}_{3}$. EPA concentration was higher than DHA in treatments with low and medium $\mathrm{NaNO}_{3}$ concentrations. However, at the highest $\mathrm{NaNO}_{3}$ concentration, the DHA concentration surpassed that of EPA. By contrast, the $\mathrm{NH}_{4} \mathrm{Cl}$ treatments yielded mixed results: the EPA and DHA concentrations were higher at moderately low and very high $\mathrm{NH}_{4} \mathrm{Cl}$ concentrations, whereas at very low and moderately high $\mathrm{NH}_{4} \mathrm{Cl}$ concentrations, these values dropped. In all four $\mathrm{NH}_{4} \mathrm{Cl}$ concentrations, EPA concentration surpassed that of DHA.

\section{Discussion}

\subsection{Microalgae Growth and Biomass Production}

As the nitrogen concentration increased in the cultures, the T. weissflogii biomass concentration and cell density increased. A decrease in algal biomass concentration in low nitrate concentration was also observed [35] in Nannochloropsis sp.

As previously described, reduced nitrogen forms as ammonium or urea are preferably used for microalgae, since nitrate must be transformed into ammonium before it is utilized assimilated by algal cells, so more energy expenditure is necessary [36,37]. This assertion remains true for lower nitrogen salt concentrations and was particularly evident for moderately low concentrations ( $\mathrm{N} 2$ and $\mathrm{C} 2$ ), where the $\mathrm{NH}_{4} \mathrm{Cl}$ yielded a biomass peak twice as large as that yielded by the $\mathrm{NaNO}_{3}$. However, high $\mathrm{NH}_{4} \mathrm{Cl}$ concentration cultures reached 
peak biomass three days later than similar $\mathrm{NaNO}_{3}$ cultures, which suggests that at high salt concentrations, $\mathrm{NaNO}_{3}$ can be assimilated slightly faster than $\mathrm{NH}_{4} \mathrm{Cl}$.

Considering only the cost per metric ton of each salt (\$200-\$430 USD ton ${ }^{-1} \mathrm{NaNO}_{3}$ vs. \$90-\$200 USD metric ton $\left.{ }^{-1} \mathrm{NH}_{4} \mathrm{Cl}\right)[38,39]$ and the amount required to run the experiment, an estimated production $\left(\mathrm{mg} \mathrm{USD}^{-1}\right)$ was computed. Since $\mathrm{NH}_{4} \mathrm{Cl}$ is less than half the price of $\mathrm{NaNO}_{3}$, treatments with low $\mathrm{NH}_{4} \mathrm{Cl}$ were the most cost-effective in all cases. All the treatments reached their most cost-effective values after 15 or 18 days. However, differences in time and growth rate were also important for estimated costs. For instance, $\mathrm{C} 1$ and $\mathrm{C} 2$ (low and moderately low $\mathrm{NH}_{4} \mathrm{Cl}$ ) provided a maximum of $>6 \mathrm{mg} \mathrm{DW} \mathrm{USD}^{-1}$ after 15 days, whereas $\mathrm{C} 3$ and $\mathrm{C} 4$ (moderately high and high $\mathrm{NH}_{4} \mathrm{Cl}$ ) provided a maximum of 3-4 mg DW USD ${ }^{-1}$ after 15 and 18 days, respectively. By contrast, N1 reached a maximum of $3.2 \mathrm{mg} \mathrm{DW} \mathrm{USD}^{-1}$ after 18 days, and N2-N4 provided only $1.44-1.68 \mathrm{mg}^{\mathrm{DW}} \mathrm{USD}^{-1}$ after 15 or 18 days.

\subsection{Biochemical Composition}

Since microalgal species can vary in nutritional value as a function of culture conditions, several studies have attempted to manipulate them with the objective of increasing biochemical products [2,40,41], protein [13], carbohydrate [35,42], lipid [43-45] and fatty acid $[16,46,47]$ contents. Many microalgal species, respond to nitrogen deficiency by increasing their lipid content. A lack of nitrogen and carbon availability allows microalgae to switch from synthetizing proteins to lipids, with correspondingly slower growth rates and lower biomass production [48]. Some strains of the genus Thalassiosira have been described as potentially harmful [49] but the production of allelochemical compounds from T. weisflogii strains with allelopathic effects against potentially harmful microalgae, such as Phaeocystis globosa, has also been reported [50].

Chlorophyll is utilized as an intracellular nitrogen pool to support further cell growth and biomass production as nitrogen in the media becomes depleted [47,51]. Chlorophyll $a$ follows a similar trend to biomass production, since chlorophyll $a$ is a nitrogen-rich compound that contains four nitrogen atoms. This suggests that cells accumulate large quantities of chlorophyll molecules when a nitrogen source is abundantly available [52] This pattern has been described in a previous research [13].

The protein content revealed maximum values in the exponential growth phase, decreasing throughout the stationary phase. Costard [13] found the same trend for five genera of microalgae from the Brazilian coast (Bellerochea sp., Van Heurck 1885; Chaetoceros sp., Ehrenberg 1844; Chlorella sp. M. Beijerinck 1890; Rhodomonas sp. Karsten 1898 and Thalassiosira sp. Cleve 1873). Silva [53] also reported a peak in the protein content of Rhodomonas in the transitional growth phase and a declination in the stationary stage.

Generally, as microalgae enter the stationary stage due to limited nutrients, cells accumulate carbon in the form of lipids and carbohydrates [13,54]. Navarro [55] observed that the lipid content tends to increase when cultures reach the stationary phase, especially when silicate and nitrogen are limited. This study proved that lipid content rises as nitrogen concentration declines in the cultures around day nine, i.e., at the onset of the stationary phase. This phenomenon was clearly observed in cultures with lower nitrogen concentrations $(111.25,222.50 \mu \mathrm{M})$. $\mathrm{Lv}$ [56] studied the effect of $\mathrm{KNO}_{3}$ concentration on the lipid concentration. Different $\mathrm{KNO}_{3}$ concentrations of $0.2,1.0,3.0$ and $5.0 \mathrm{mM}$ were applied to Chlorella vulgaris cultures and demonstrated that the lipid content decreased as the $\mathrm{KNO}_{3}$ concentration increased.

\subsection{Fatty Acids}

The use of microalgae as natural sources of fatty acids for aquaculture has become the focus of scientific developments in recent years, particularly PUFA content, which performs specific physiological functions as a phospholipid biomembrane component [8].

In this study, the fatty acid content of $T$. weissflogii fatty was predominantly represented by SAFA and PUFA, which increased with lower nitrogen concentration cultures and culture 
age. The fatty acid component can be modified by the nitrogen concentration and source. The presence of $\mathrm{NH}_{4}{ }^{+}$stimulates the activity of desaturases, which catalyzes the formation of double bonds, forming unsaturated fatty acids; the highest PUFA levels were noted with the $\mathrm{NH}_{4} \mathrm{Cl}$ source. The major fatty acids were eicosapentaenoic acid (EPA, 20:5n3) and docosahexaenoic (DHA, 22:6n3). EPA results have been reported for T. weissflogii and other diatom strains as one of the major fatty acid contents [57-60].

\title{
5. Conclusions
}

Higher nitrogen concentrations influenced T. weissflogii cell metabolism, increasing cell biomass and protein content. By contrast, low nitrogen concentrations increased lipid concentration, probably due to their storage of cell reserves. In most cases, the carbohydrate concentrations also increased with nitrogen limitation.

With respect to production, moderately low $\mathrm{NH}_{4} \mathrm{Cl}$ treatment $(\mathrm{C} 2)$ proved to be highly efficient in EPA, moderately efficient in DHA, and the most cost-effective in terms of biomass; no variations were observed in protein content with culture age. Concentrations of $\mathrm{NH}_{4} \mathrm{Cl}$ close to $222 \mu \mathrm{M}$ were considered the best option for cultivating T. weissflogii as food for the growth of marine larvae of commercial interest. However, if the goal is to maximize $\mathrm{DHA}$ production, $\mathrm{NaNO}_{3}$ at $890 \mu \mathrm{M}$ should be considered for rearing purposes.

\begin{abstract}
Author Contributions: Conceptualization, methodology, investigation and writing - original draft preparation, F.E.H.-S.; formal analysis and writing-review and editing J.A.D.Á.-R.; supervision, writing — review and editing E.J.N.-V.; writing—review and editing, C.J.B.-S.; resources and writingreview and editing B.O.A.-V.; writing-review and editing Á.I.C.-C.; data curation and software, M.M.-L.; visualization and editing L.J.F.-H.; conceptualization, writing-original draft preparation and funding acquisition, D.J.L.-C. All authors have read and agreed to the published version of the manuscript.
\end{abstract}

Funding: This research was funded by the institutional projects PC 0.11, PC 0.12 and AC0.8 (CIBNOR) and the student fellowship CONACyT 126348.

Institutional Review Board Statement: Not applicable for studies not involving humans or animals.

Informed Consent Statement: Not applicable.

Data Availability Statement: Not applicable.

Acknowledgments: The authors thank Laura Carreon-Palau for her assistance in the GC-MS analysis; Gerardo García for his help in the preparation of the figures; W. Johnson and Miguel Cordoba-Matson for improving the English version; and Diana Fischer for English editing.

Conflicts of Interest: The authors declare no conflict of interest.

\section{References}

1. FAO-Food and Agriculture Organization of the United Nations. The State of World Fisheries Aquaculture; FAO Fisheries and Aquaculture Department: Rome, Italy, 2010; p. 197. ISBN 978-92-5-106675-1.

2. Lavens, P.; Sorgeloos, P. Manual on the Production and Use of Live Food for Aquaculture; FAO Fisheries Technical: Rome, Italy, 1996; p. 295, Paper No. 361.

3. Knauer, J.; Southgate, P.C.A. Review of the Nutritional Requirements of Bivalves and the Development of Alternative and Artificial Diets for Bivalve Aquaculture. Rev. Fish. Sci. 1999, 7, 241-280. [CrossRef]

4. Aji, L.P. The Use of Algae Concentrates Dried Algae and Algal Substitutes to Feed Bivalves. Makara Sains 2011, 15, 1-8.

5. Sukenik, A.; Zmora, O.; Carmeli, Y. Biochemical Quality of Marine Unicellular Algae with Special Emphasis on Lipid Composition. II Nannochloropsis sp. Aquaculture 1993, 117, 313-326. [CrossRef]

6. Volkman, J.K.; Jeffrey, S.W.; Nichols, P.D.; Rogers, G.I.; Garland, C.D. Fatty Acid and Lipid Composition of 10 Species of Microalgae Used in Mariculture. J. Exp. Mar. Biol. Ecol. 1989, 128, 219-240. [CrossRef]

7. Becker, E.W. Micro-algae as a Source of Protein. Biotechnol. Adv. 2007, 25, 207-210. [CrossRef]

8. Patil, V.; Källqvist, T.; Olsen, E.; Vogt, G.; Gislerød, H.R. Fatty Acid Composition of 12 Microalgae for Possible Use in Aquaculture Feed. Aquacult. Int. 2007, 15, 1-9. [CrossRef]

9. Ehteshami, F.; Christianus, A.; Rameshi, H.; Harmin, S.A.; Saad, C.R. Proximate and Fatty Acid Composition of the Gonads of Wild versus Hatchery-Conditioned Pinctada margaritifera Broodstock. Aquacul. Nut. 2011, 17, 675-682. [CrossRef] 
10. Kiatmetha, P.; Siangdang, W.; Bunnag, B.; Senapin, S.; Withyachumnarnkul, B. Enhancement of Survival and Metamorphosis Rates of Penaeus monodon Larvae by Feeding with the Diatom Thalassiosira weissflogii. Aquacul. Int. 2011, 19, 599-609. [CrossRef]

11. Kiron, V.; Phromkunthong, W.; Huntley, M.; Archibald, I.; De Scheemaker, G. Marine Microalgae from Biorefinery as a Potential Feed Protein Source for Atlantic Salmon, Common Carp and Whiteleg Shrimp. Aquacult. Nutr. 2012, 18, 521-531. [CrossRef]

12. Liu, Z.Y.; Wang, G.C.; Zhou, B.C. Effect of Iron on Growth and Lipid Accumulation in Chlorella vulgaris. Bioresour. Technol. 2008, 99, 4717-4722. [CrossRef] [PubMed]

13. Costard, G.S.; Machado, R.R.; Barbarino, E.R.; Martino, C.; Lourenço, S.O. Chemical Composition of Five Marine Microalgae that Occur on the Brazilian Coast. Int. J. Fish. Aquacult. 2012, 4, 191-201.

14. Garcia, N.; Lopez-Elias, J.A.; Miranda, A.; Martinez-Porchas, M.; Huerta, N.; Garcia, A. Effect of Salinity on Growth and Chemical Composition of the Diatom Thalassiosira weissflogii at Three Culture Phases. Lat. Am. J. Aquat. Res. 2012, 40, 435-440. [CrossRef]

15. Moronta, R.; Mora, R.; Morales, E. Respuesta de la Microalga Chlorella sorokiniana al pH, Salinidad y Temperatura en Condiciones Axénicas y no Axénicas. La Rev.Fac.Agron. 2006, 23, 27-41.

16. Pacheco, J.M.; Cadena, M.A.; Sánchez, M.P.; Tovar, R.D.; Rangel, D.C. Effect of Culture Medium and Nutrient Concentration on Fatty Acid Content of Chaetoceros muelleri. Revista Latinoam. Biotecnol. Ambient. Algal. 2010, 1, 6-15.

17. Renaud, S.M.; Thinh, L.V.; Parry, D.L. The Gross Chemical Composition and Fatty Acid Composition of 18 Species of Tropical Australian Microalgae for Possible Use in Mariculture. Aquaculture 1999, 170, 147-159. [CrossRef]

18. Gouveia, L.; Oliveira, A.C. Microalgae as a Raw Material for Biofuels Production. J. Ind. Microbiol. Biotechnol. 2009, 36, 269-274. [CrossRef]

19. Pruvost, J.; Vooren, G.; Gouic, B.; Mossion, A.; Legrand, J. Systematic Investigation of Biomass and Lipid Productivity by Microalgae in Photobioreactors for Biodiesel Application. Bioresour. Technol. 2011, 102, 150-158. [CrossRef]

20. Lourenco, S.O.; Barbarino, E.; Mancini-Filho, J.; Schinke, K.P.; Aldar, E. Effects of Different Nitrogen Sources on the Growth and Biochemical Profile of 10 Marine Microalgae in Batch Culture: An Evaluation for Aquaculture. Phycologia 2002, 41, 158-168. [CrossRef]

21. Guillard, R.R. Culture of Phytoplankton for Feeding Marine Invertebrate Animals. Culture of Marine Invertebrate Animals; Smith, W.L., Chanley, M.H., Eds.; Plenum Press: New York, NY, USA, 1975; pp. $29-60$.

22. Verhulst, P.F. Recherches mathématiques sur la loi d'accroissement de la population [Mathematical Researches into the Law of Population Growth Increase]. Nouv. Mém. L'académie R. Sci. Belles-Lett. Brux. 1845, 18, 1-42.

23. McKendrick, A.; Pai, M. The Rate of Multiplication of Micro-organisms: A Mathematical Study. Proc. R. Soc. Edinb. 1912, 31, 649-655. [CrossRef]

24. Pearl, R.; Reed, L. On the Rate of Growth of the Population of the United States. Proc. Natl. Acad. Sci. USA 1920, 6, 275-288. [CrossRef]

25. Guillard, R.R.L.; John, H.; Ryther, J.H. Studies of marine planktonic diatoms: I. Cyclotella nana Hustedt, and Detonula confervacea (Cleve) Gran. Can. J. Microbiol. 1962, 8, 229-239. [CrossRef]

26. Levasseur, M.; Thompson, P.A.; Harrison, P.J. Physiological acclimation of marine phytoplankton to different nitrogen sources. J. Phycol. 1993, 29, 587-595. [CrossRef]

27. Zhang, X.; Wen, Y.; Yang, S.T. Modes of Culture/Animal Cells. In Comprehensive Biotechnology, 2nd ed.; Murray, M.Y., Ed.; Academic Press: Cambridge, MA, USA, 2011; pp. 285-302.

28. Lowry, O.H.; Rosebrough, N.J.; Farr, A.L.; Randall, R.J. Protein Measurement with the Folin-Phenol Reagent. J. Biol. Chem. 1951, 193, 265-275. [CrossRef]

29. Dubois, M.; Gilles, K.A.; Hamilton, J.D.; Rebers, P.A.; Smith, F. Colorimetric Method for Determination of Sugars and Related Substances. Anal. Chem. 1956, 28, 350-356. [CrossRef]

30. Vidussi, F.; Claustre, H.; Bustillos, G.J.; Cailiau, C.; Marty, J.C. A Rapid HPLC Method for the Determination of Phytoplankton Pigments in Natural Waters Including the Separation of Chlorophyll $a$ from Divinyl-chlorophyll $a$ and Zeaxathin from Lutein. $J$. Plankton Res. 1996, 18, 2377-2382. [CrossRef]

31. Bligh, E.G.; Dyer, W.J. A Rapid Method of Total Lipid Extraction and Purification. Can. J. Biochem. Physiol. 1959, 37, 911-917. [CrossRef]

32. Marsh, J.B.; Weinstein, D.B. Simple Charring Method for Determination of Lipids. J. Lip. Res. 1966, 7, 574-576. [CrossRef]

33. Sato, N.; Murata, N. Membrane Lipids. Methods Enzymol. 1988, 167, 251-259.

34. Zar, J. Biostatitical Analysis; Prentice Hall: Englewood Cliffs, NJ, USA, 1999; p. 663.

35. Huertas, E.; Montero, O.; Lubian, L.M. Effects of Dissolved Inorganic Carbon Availability on Growth, Nutrient Uptake and Chlorophyll Fluorescence of two Marine Microalgae. Aquac. Eng. 2000, 22, 181-197. [CrossRef]

36. Chitra, R.S.; Sumitra, V.C.; Yash, S. Effect of Different Nitrogen Sources and Plant Growth Regulators on Glutamine Synthetase and Glutamate Synthase Activities of Radish cotyledons. Bul. J. Plant Physiol. 2002, 28, 46-56.

37. Rees, T.A. Metabolic and Ecological Constraints Imposed by Similar Rates of Ammonium and Nitrate Uptake per Unit Surface Area at Low Substrate Concentrations in Marine Phytoplankton and Macroalgae. J. Phycol. 2007, 43, $197-207$.

38. Available online: https://www.made-in-china.com/products-search/hot-china-products/nano3_price.html (accessed on 6 November 2021).

39. Available online: https://www.made-in-china.com/products-search/hot-china-products/nh4cl_price.html (accessed on 6 November 2021). 
40. Fu, W.; Wichuk, K.; Brynjólfsson, S. Developing diatoms for value-added products: Challenges and opportunities. N. Biotechnol. 2015, 32, 547-551. [CrossRef]

41. Vinayak, V.; Manoylov, K.M.; Gateau, H.; Blanckaert, V.; Hérault, J.; Pencréac’h, G.; Marchand, J.; Gordon, R.; Schoefs, B. Diatom Milking: A Review and New Approaches. Mar. Drugs 2015, 13, 2629-2665. [CrossRef]

42. Sánchez, A.; Cerón, M.; García, F.; Molina, E.; Chisti, Y. Growth and Biochemical Characterization of Microalgal Biomass Produced in Bubble Column and Airlift Photobioreactors: Studies in Fed-Batch Culture. Enzyme Microb. Technol. 2002, 31, 1015-1023. [CrossRef]

43. Lee, Y.C.; Kim, B.; Farooq, W.; Chung, J.; Han, H.; Shin, J.; Jeong, H.; Park, J.; Lee, S.; Oh, K. Harvesting of Oleaginous Chlorella sp. by Organoclays. Bioresour. Technol. 2013, 132, 440-445. [CrossRef] [PubMed]

44. Gatenby, C.M.; Orcutt, D.M.; Kreeger, D.A.; Parker, B.C.; Jones, V.A.; Neves, R.J. Biochemical Composition of Three Algal Species Proposed as Food for Captive Freshwater Mussels. J. Appl. Phycol. 2003, 5, 1-11. [CrossRef]

45. Yi, Z.; Xu, M.; Di, X.; Brynjolfsson, S.; Fu, W. Exploring Valuable Lipids in Diatoms. Front. Mar. Sci. 2017, 4, 17. [CrossRef]

46. Li, Y.; Horsman, M.; Wang, B.; Wu, N.; Lan, C.Q. Effects of Nitrogen Sources on Cell Growth and Lipid Accumulation of Green Algae Neochloris oleoabundans. Appl. Microbiol. Biotechnol. 2008, 81, 629-636. [CrossRef] [PubMed]

47. Sabia, A.; Clavero, E.; Pancaldi, S.; Salvadó, R.J. Effect of different $\mathrm{CO}_{2}$ concentrations on biomass, pigment content, and lipid production of the marine diatom Thalassiosira pseudonana. Appl. Microbiol. Biotechnol. 2018, 102, 1945-1954. [CrossRef] [PubMed]

48. Liang, Y.; Kangsen, M. Effect of Growth Phase on the Fatty Acid Compositions of Four Species of Marine Diatoms. J. Ocean Univ. China. 2005, 4, 157-162. [CrossRef]

49. Fryxell, G.A.; Hasle, G.R. Taxonomy of diatoms. In Manual on Harmful Marine Microalgae; Hallegraeff, G.M., Andersen, D.M., Cembella, A.D., Eds.; UNESCO: Paris, France, 2003; pp. 465-510.

50. Wang, X.; Huo, Y.; Yang, F.; Wang, Y. Induced Allelopathic Effects of Thalassiosira weissflogii on Colony Formation in Phaeocystis globosa. Water 2021, 13, 581. [CrossRef]

51. Brennan, L.; Owende, P. Biofuels from Microalgae-A Review of Technologies for Production, Processing, and Extractions of Biofuels and Co-Products. Renew. Sust. Energ. Rev. 2010, 14, 557-577. [CrossRef]

52. Ördöget, V.; Stirk, W.A.; Bálint, P.; Staden, J.; Lovász, C. Changes in Lipid, Protein and Pigment Concentrations in NitrogenStressed Chlorella minutissima Cultures. J. Appl. Phycol. 2012, 24, 907-914. [CrossRef]

53. Silva, A.F.; Lourenco, S.O.; Chaloub, R.M. Effects of Nitrogen Starvation on the Photosynthetic Physiology of a Tropical Marine Microalgae Rhodomonas sp. (Cryptophyceae). Aquat. Bot. 2009, 91, 291-297. [CrossRef]

54. Makarevičienè, V.; Andrulevičiūt, V.; Skorupskaitè, V.; Kasperovičienè, J. Cultivation of Microalgae Chlorella sp. and Scenedesmus sp. as a Potentional Biofuel Feedstock. Environ. Res. Eng. Manage. 2011, 3, 21-27.

55. Navarro, P.A.; Rebolloso, M.M.; Ramos, J.J.; Guil, J.L. Biomass Nutrient Profiles of the Microalgae Phaeodactylum tricornutum. J. Food Biochem. 2001, 25, 57-76.

56. Lv, J.M.; Cheng, L.H.; Xu, X.H.; Zhang, L.; Chen, H.L. Enhanced Lipid Production of Chlorella vulgaris by Adjustment of Cultivation Conditions. Bioresour. Technol. 2010, 101, 6797-6804. [CrossRef]

57. Marella, T.K.; Tiwari, A. Marine diatom Thalassiosira weisflogii based biorefinery for co-production of eicosapentaenoic acid and fucoxanthin. Bioresour. Technol. 2020, 307, 123245. [CrossRef] [PubMed]

58. d'Ippolito, G.; Sardo, A.; Paris, D.; Vella, F.M.; Adelfi, M.G.; Botte, P.; Gallo, C.; Fontana, A. Potential of lipid metabolism in marine diatoms for biofuel production. Biotechnol. Biofuels. 2015, 8, 28. [CrossRef] [PubMed]

59. Ryckebosch, E.; Bruneel, C.; Termote-Verhalle, R.; Goiris, K.; Muylaert, K.; Foubert, I. Nutritional evaluation of microalgae oils in omega-3 chain polyunsaturated fatty acid as an alternative for fish oil. Food Chem. 2014, 160, 393-400. [CrossRef]

60. Kumar, B.R.; Deviram, G.; Mathimani, T.; Duc, P.A.; Pugazhendhi, A. Microalgae as rich source of polyunsaturated fatty acids. Biocatal. Agric. Biotechnol. 2019, 17, 583-588. [CrossRef] 